\title{
Role of the extra-follicular compartment in the ovulation of isolated rabbit ovarian follicles
}

\author{
A. Thébault, Brigitte Lefèvre and J. Testart \\ Laboratoire de Physiologie et Psychologie de la Reproduction Humaine, INSERM U. 187, \\ Hôpital Antoine Béclère, 157 rue de la Porte de Trivaux, 92141 Clamart, France
}

\begin{abstract}
Summary. Ovulation was never observed, even in the presence of gonadotrophins, when preovulatory follicles isolated from oestrous does were cultured in vitro $(n=112)$. If the follicles were co-cultured with pieces of ovarian tissue and gonadotrophins, then $50 \%$ ovulated $(P<0.01)$. Attempts to replace the ovarian tissue by various steroid hormones or prostaglandins did not result in follicular rupture except when PGE-2 was used $(23.8 \%, P<0.05)$. We suggest that gonadotrophins have an immediate $(<1 \mathrm{~h})$ action upon the follicle and ovarian interstitial tissue simultaneously. The response of the ovarian tissue to gonadotrophins is essential for eventual follicular rupture and involves PGE-2.
\end{abstract}

\section{Introduction}

Ovulation may occur in vitro in whole ovaries cultured in the presence of gonadotrophins in a number of mammalian species (rabbit: Lambertsen, Greenbaum, Wright \& Wallach, 1976; Janson et al., 1982; rat: Osman \& Lieuwma-Noordanus, 1980; mouse: Fritz, Chow \& Biggers, 1965; hamster: Baranczuk \& Fainstat, 1976; Osman \& Lieuwma-Noordanus, 1980). When rabbit preovulatory follicles were isolated from ovaries $1 \mathrm{~h}$ post coitum (p.c.) and cultured in hormone-free medium, almost half of them ovulated (Testart, Thébault \& Lefèvre, 1983). The technique of culturing isolated follicles in vitro permits the separation of factors coming from the follicle and those originating from the extra-follicular compartment of the ovary, thereby enabling analysis of their respective roles in the ovulation process. Rupture of isolated follicles in vitro is very similar (chronology, morphology) to that described for follicles ruptured in vivo and may be obtained even if the follicles are removed from the ovaries very soon $(<1 \mathrm{~h})$ after the endogenous gonadotrophin discharge (Testart et al., 1983).

In the present study, preovulatory follicles were isolated before the gonadotrophin surge to determine whether gonadotrophins act directly and solely upon the follicular compartment in vitro. Possible roles in the process of ovulation for certain compounds normally produced by the ovary have also been investigated.

\section{Materials and Methods}

New Zealand does, 4-6 months of age, were used during natural oestrus. The does were not treated in any way and nor were they kept with males. The ovaries were excised immediately after killing and the follicles, isolated by dissection, were cultured in vitro using a flow system with continuous gassing (Ménézo, Gérard \& Thibault, 1976) for $14 \mathrm{~h}$. Details of the techniques for preparation and 
culture of the follicles are fully described by Testart et al. (1983). Ovaries were cultured in the presence of gonadotrophins (Exp. 1), in the presence of gonadotrophins and pieces of ovarian tissue (Exp. 2), and in the presence of gonadotrophins and various substances (steroid hormones or prostaglandins) which may be produced by the ovarian tissue (Exp. 3).

For the co-culture experiments (Exp. 2) the pieces of ovarian tissue were placed in an extraculture chamber interposed in the flow circuit immediately before the chamber containing the follicles. The ovarian tissue used for co-culture contained no corpora lutea or visible follicles and was diced with fine scissors into pieces equivalent in size to the follicles. Pieces of 2 ovaries from the does whose follicles were being cultured were placed in co-culture with $10-15$ follicles. All substances whose effects upon ovulation were being investigated were introduced into the circulating medium from the start of the culture period. The substances used were hypophysial hormones (NIH, Bethesda, Maryland, U.S.A.), steroid hormones (Roussel, Paris, France) and prostaglandins (Upjohn, Kalamazoo, Michigan, U.S.A.).

The hypophysial hormones were all of ovine origin and were follicle-stimulating hormone (NIH FSH-S12, $1 \mu \mathrm{g} / \mathrm{ml}$ ), luteinizing hormone (NIH LH-S20, $0.5 \mu \mathrm{g} / \mathrm{ml}$ ) and prolactin (NIH-PRL-S12, 2 $\mu \mathrm{g} / \mathrm{ml})$. The steroids were oestradiol-17 $\beta(1 \mu \mathrm{g} / \mathrm{ml})$, androst-4-en-3,17-dione $(1 \mu \mathrm{g} / \mathrm{ml})$ and $20 \alpha$ dihydroprogesterone $(10 \mu \mathrm{g} / \mathrm{ml})$. Prostaglandins (PG) E-2 and F-2 $\alpha$ were both used at a concentration of $10 \mu \mathrm{g} / \mathrm{ml}$.

Differences between proportions of ovulating follicles were examined by $\chi^{2}$ tests.

\section{Results}

\section{Experiment 1}

Isolated follicles cultured in hormone-free medium for $14 \mathrm{~h}$ did not undergo rupture $(0 / 48,8$ rabbits). When the medium was supplemented with FSH + LH from the start of the culture period ovulation was still not achieved (0/52, 9 rabbits), and the additional presence of prolactin did not change the results $(0 / 12,3$ rabbits $)$.

\section{Experiment 2}

Co-culture of follicles with ovarian tissue only rarely led to ovulation in the absence of gonadotrophins $(1 / 13$, i.e. $7 \cdot 7 \%, 3$ rabbits). When FSH and $\mathrm{LH}$ were added to the culture system half the follicles had ovulated by $14 \mathrm{~h}$ of culture $(8 / 16,3$ rabbits, $P<0.05)$. Gonadotrophins were only able to support ovulation in vitro if the follicles were co-cultured with ovarian tissue (0/64 in Exp. 1 compared with $8 / 16$ in Exp. $2, P<0.01$ ).

Table 1. In-vitro ovulation of rabbit follicles cultured with gonadotrophins (1 $\mu \mathrm{g}$ $\mathrm{FSH} / \mathrm{ml}+0.5 \mu \mathrm{g} \mathrm{LH} / \mathrm{ml}$ ) and steroid hormones or prostaglandins (Exp. 3)

\begin{tabular}{|c|c|c|c|c|}
\hline \multirow[b]{2}{*}{$\begin{array}{l}\text { Cultured medium supplemented } \\
\text { with }\end{array}$} & \multicolumn{3}{|c|}{ Number of: } & \multirow[b]{2}{*}{$\begin{array}{l}\% \text { ovulating } \\
\text { follicles }\end{array}$} \\
\hline & Rabbits & $\begin{array}{l}\text { Cultured } \\
\text { follicles }\end{array}$ & $\begin{array}{l}\text { Ovulating } \\
\text { follicles }\end{array}$ & \\
\hline $\begin{array}{l}\text { Oestradiol }(1 \mu \mathrm{g} / \mathrm{ml})+ \\
\quad \text { androstenedione }(1 \mu \mathrm{g} / \mathrm{ml})\end{array}$ & 10 & 59 & 0 & 0.0 \\
\hline $20 \alpha$-Dihydroprogesterone & & & & \\
\hline$(1 \mu \mathrm{g} / \mathrm{ml})$ & 9 & 41 & 2 & $4 \cdot 4$ \\
\hline PGF- $2 \alpha(10 \mu \mathrm{g} / \mathrm{ml})$ & 5 & 21 & 0 & 0.0 \\
\hline PGE-2 $(10 \mu \mathrm{g} / \mathrm{ml})$ & 9 & 42 & 10 & $23 \cdot 8^{*}$ \\
\hline
\end{tabular}

${ }^{*} P<0.001$ compared with all 3 other tests combined $\left(\chi^{2}\right.$ test). 


\section{Experiment 3}

Amongst the substances tested steroid hormones or PGF- $2 \alpha$ were unable to replace co-cultured ovarian tissue in supporting ovulation in vitro (Table 1). However PGE-2 induced rupture in $24 \%$ of follicles. The incidence of ovulation in the presence of PGE-2 was much greater than for the other substances tested (10/42 compared with $2 / 121, P<0.001$ ), and was not statistically different from that obtained by co-culture with ovarian tissue $(8 / 16, P>0.05)$.

\section{Discussion}

While gonadotrophins are able to induce ovulation when acting upon the whole ovary, in vivo or in vitro, they are ineffective when acting upon the isolated follicle. In this respect the present study complements the report of D'Amato, Calvo, Stockert \& Bahr (1981) who did not find any ovulations in isolated follicles cultured for 18-24 h. An ovarian factor of extra-follicular origin would therefore appear to be implicated. This factor would not seem to result from the physical changes described by Espey $(1978,1980)$ since follicles isolated very soon after the endogenous gonadotrophin discharge were able to rupture spontaneously in vitro (Testart et al., 1983). Follicular rupture can also occur if pieces of ovarian tissue are co-cultured with the follicles in the presence of gonadotrophins, indicating that one or more substances released by the ovarian interstitial tissue under gonadotrophin control are necessary for follicular rupture.

It is known that the extra-follicular compartment of the ovary is able to produce a number of substances under gonadotrophin stimulation, in particular steroid hormones (Hilliard, Spies \& Sawyer, 1969; Koering \& Sholl, 1978; McNatty, Makris, De Grazia, Osathanondh \& Ryan, 1979; Taya, Saidapur \& Greenwald, 1980). Facilitatory actions of progestagens (Mōri, Suzuki, Nishimura \& Kambegawa, 1977a; Hamada, Wright \& Wallach, 1979), and androgens (Mōri et al., $1977 \mathrm{~b}$ ) on the mechanism of ovulation have been described. However, supplementation of the culture medium with oestradiol or androstenedione did not cause ovulation in isolated follicles (Table 1). A very weak effect of $20 \alpha$-dihydroprogesterone which is produced in abundant quantities by the ovary in vivo (Hilliard, Penardi \& Sawyer, 1967) was obtained (1/28 follicles ovulated).

The failure of the present attempts to induce ovulation by substituting various steroid hormones for pieces of ovarian tissue indicates that the extra-follicular ovarian compartment does not affect follicular rupture by producing any of these hormones, or some precursor(s). An action of PGE and PGF in the regulation of follicular rupture has been suggested since there is a rapid increase in their secretion in the rabbit follicle during the immediate preovulatory period (LeMaire, Yang, Behrman \& Marsh, 1973), and also from the blockage of ovulation by inhibitors of PG synthesis both in the rabbit (O'Grady, Caldwell, Auletta \& Speroff, 1972) and the rat (Armstrong \& Grinwich, 1972; Tsafriri, Lindner, Zor \& Lamprecht, 1972). While the involvement of PGs is essential for the occurrence of follicular rupture, the method of action and the class of prostaglandins involved remain uncertain.

PGF- $2 \alpha$ was believed to be the most efficient prostaglandin in this respect since its secretion is maximal approximately $2 \mathrm{~h}$ before follicular rupture in the rabbit (LeMaire et al., 1973). Furthermore, PGF- $2 \alpha$ is able to restore ovulation in animals treated with indomethacin (Armstrong, Moon \& Zamecnik, 1973; Diaz-Infante, Wright \& Wallach, 1974; Wallach, Bronson, Hamada, Wright \& Stevens, 1975). However, in the present study, the addition of PGF-2 $\alpha$ (10 $\mu \mathrm{g} / \mathrm{ml}$ ) was completely ineffective in inducing rupture of isolated follicles. If PGF- $2 \alpha$ is involved in follicular rupture, by its well-described effect on contractility, then this effect was insufficient to cause rupture of the follicle in vitro, at least at the concentration used. This finding confirms the hypothesis of Espey (1978) that PGF-2 $\alpha$ was not essential in the process of ovulation. Conversely, the culture of follicles in the presence of PGE- 2 resulted in ovulation in $23.8 \%$ of cases, although the effectiveness of PGE-2 appears to be less than that of ovarian tissue in co-culture. 
After inhibition of PG synthesis in rats with indomethacin in vivo, Tsafriri, Koch \& Lindner (1973) induced ovulation by administering PGE. This would suggest that the effect observed in the present in-vitro study is in fact a reflection of the mechanism of ovulation in vivo. Prostaglandins are synthesized very rapidly by the ovary under the influence of gonadotrophins (Chasalow \& Pharriss, 1972), and this immediate synthesis does not need to be reinforced, at least at the extra-follicular level, since follicles isolated at only $1 \mathrm{~h}$ p.c. are capable of ovulating in vitro with no further exogenous stimulation (Testart et al., 1983).

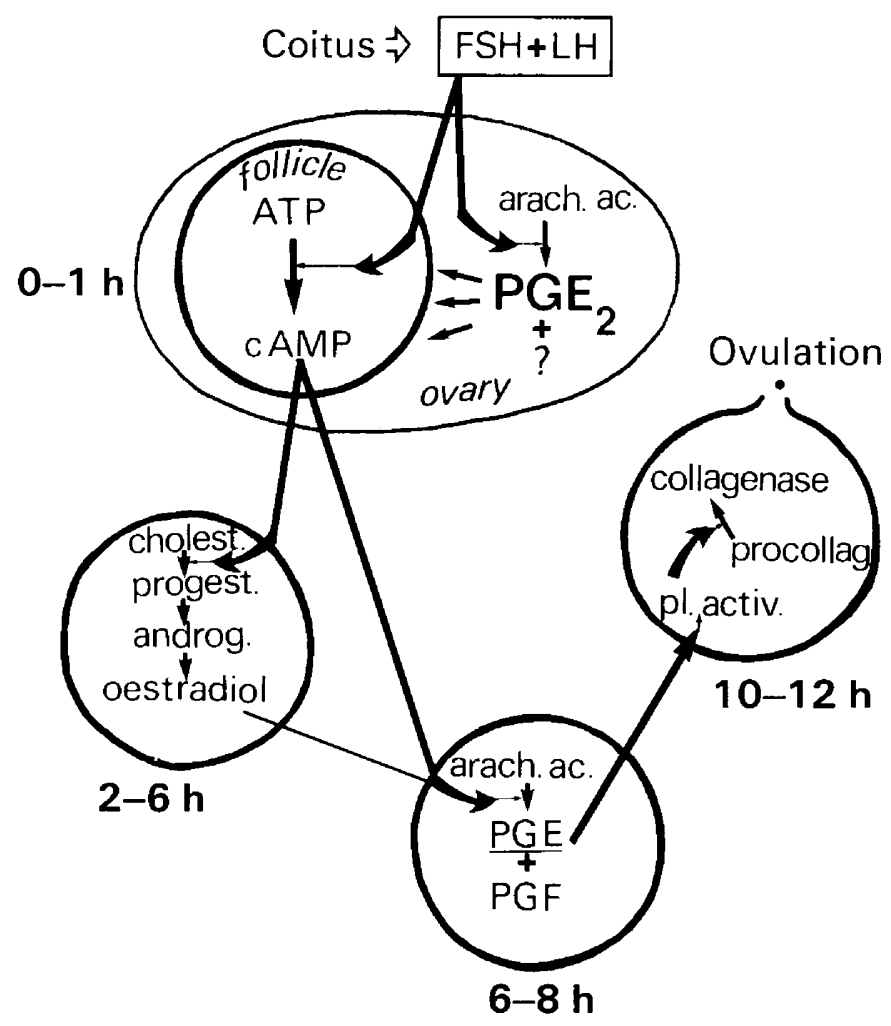

Text-fig. 1. Suggested sequence of events during the ovulatory process in the rabbit. Follicular rupture requires action of the interstitial tissue; this action occurs quickly $(0-1 \mathrm{~h})$ after the gonadotrophin stimulation and seems to involve PGE-2. The next events do not require the presence of the ovarian tissue: $2-6 \mathrm{~h}$, high steroid synthesis (cholesterol $\rightarrow$ progesterone $\rightarrow$ androgen $\rightarrow$ oestradiol); 6-8 h, PG synthesis from arachidonic acid; 10-12 h, transformation of procollagenase into collagenase by plasminogen activator; ovulation. For further details see Espey $(1978,1980)$.

Prostaglandin E-2 induces ovarian synthesis of progesterone in the rat (Lindner et al., 1974) and the mouse (Neal, Baker, McNatty \& Scaramuzzi, 1975), but culture of rabbit follicles in the presence of PGE-2 increases the concentration of progestagens in the culture medium only slightly YoungLai, 1978) or not at all (Thébault, 1979). If progestagens are an important link in the process of ovulation (Mōri et al., 1977a; Hamada et al., 1979; Testart et al., 1983) it would appear that their action is only facilitatory and that they act only in combination with other conditions which are themselves essential for follicular rupture. Other methods of action for PGE-2 likely to lead to ovulation could be through increases in the production of cAMP, plasminogen activator and collagenase, or the induction of follicular hyperaemia (Espey, 1980). This last action would not seem to be essential since follicles deprived of all vascularization are able to ovulate in vitro. 
Interstitial tissue acts rapidly upon the follicie after gonadotrophin stimulation, and this action may be of very short duration $(<1 \mathrm{~h})$. Whatever the mode of action of prostaglandins in the induction of follicular rupture it is possible to propose a scheme for the sequence of events from the published observations and the present results (see Text-fig. 1). This scheme is in agreement with the two mechanisms of prostaglandins which operate at different stages of the preovulatory process as proposed by Mōri et al. (1980). It also may offer an explanation of the curious observation of intraovarian ovulation in the rat (Osman \& Dullaart, 1976) and the rabbit (O. Bomsel-Helmreich, personal communication), when indomethacin is given just before or just after ovulation induction. In such cases the inhibitor hinders the immediate synthesis of PGE-2 by the interstitial tissue but it does not block further synthesis of PGs by the follicle. Also, if the preovulatory changes in the follicular wall induced by PGE-2 (and mediated by various substances such as cAMP, plasminogen activator and collagenase) are diminished or inhibited while the follicular or ovarian contractility is maintained by PGF- $2 \alpha$, there may be inadequate local weakening of the follicular wall. This would lead to a randomly located rupture of the follicular wall, the location of which would be determined by the weakest zone of the wall. In this respect the region whose resistance to rupture would be greatest is that where the thecae are reinforced by the ovarian epithelium, i.e. the apical region.

The present study has described an action of the interstitial tissue on the follicle, an effect essential for follicular rupture. Prostaglandin E-2 is able to, at least partly, reproduce this action, but other substances of ovarian origin, even the cybernins (Channing et al., 1982), may also be involved in this intra-ovarian regulation of ovulation.

\section{References}

Armstrong, D.T. \& Grinwich, D.L. (1972) Blockage of spontaneous and LH-induced ovulation in rats by indomethacin, an inhibitor of prostaglandin biosynthesis. Prostaglandins 1, 21-28.

Armstrong, D.T., Moon, Y.S. \& Zamecnik, J. (1973) Evidence for a role of ovarian prostaglandins in ovulation. In Gonadotropins and Gonadal Function, pp. 345-356. Ed. N. R. Moudgal. Academic Press, New York.

Baranczuk, R.J. \& Fainstat, T. (1976) In-vitro ovulation from adult hamster ovary. Am. J. Obstet. Gynec. 124, $517-522$.

Channing, C.P., Anderson, L.D., Hoover, D.J., Kolena, J., Osteen, K.G., Pomerantz, S.H. \& Tanabe, K. (1982) The role of nonsteroidal regulators in control of oocyte and follicular maturation. Recent Prog. Horm. Res. 38, 331-408.

Chasalow, F. \& Pharriss, B. (1972) Luteinizing hormone stimulation of ovarian prostaglandin biosynthesis. Prostaglandins 1, 107-117.

D'Amato, C., Calvo, F.O., Stockert, B. \& Bahr, J.M. (1981) Steroid secretion by perfused rabbit follicles: effect of repeated gonadotropin challenges. Biol. Reprod. 25, 843-850.

Diaz-Infante, A., Wright, K.H. \& Wallach, E.E. (1974) Effect of indomethacin and prostaglandin $F-2 \alpha$ on ovulation and ovarian contractility in the rabbit. Prostaglandins 5, 567-581.

Espey, L.L. (1978) Ovarian contractility and its relationship to ovulation: a review. Biol. Reprod. 19, 540-551.

Espey, L.L. (1980) Ovulation as an inflammatory reaction. A hypothesis. Biol. Reprod. 22, 73-106.

Fritz, H.I., Chow, K. \& Biggers, J.D. (1965) Ovulation from whole ovaries of mice in organ culture. $J$. Cell Biol. 27, 31A, Abstr.
Hamada, Y., Wright, K.H. \& Wallach, E.E. (1979) The effects of progesterone and human chorionic gonadotropin on ovulation in the in vitro perfused rabbit ovary. Fert. Steril. 32, 335-339.

Hilliard, J., Penardi, R. \& Sawyer, C.H. (1967) A functional role for $20 \alpha$-hydroxypregn-4-en-3-one in the rabbit. Endocrinology 80, 901-909.

Hilliard, J., Spies, H.J. \& Sawyer, C.H. (1969) Hormonal factors regulating ovarian cholesterol mobilization and progestin secretion in intact and hypophysectomized rabbits. In The Gonads, pp. 55-92. Ed. K. W. McKerns. Appleton Century Crofts, New York.

Janson, P.O., LeMaire, W.J., Källfelt, B., Holmes, P.V., Cajander, S., Bjersing, L., Wiqvist, N. \& Ahrén, K. (1982) The study of ovulation in the isolated perfused rabbit ovary. I. Methodology and pattern of steroidogenesis. Biol. Reprod. 26, 456-465.

Koering, M.J. \& Sholl, S.A. (1978) Ovarian interstitial gland tissue and serum progestin levels during the first periovulatory period in the mated rabbit. Biol. Reprod. 19, 936-948.

Lambertsen, C.J., Greenbaum, D.F., Wright, K.H. \& Wallach, E.E. (1976) In-vitro studies of ovulation in the perfused rabbit ovary. Fert. Steril. 27, 178-187.

LeMaire, W.J., Yang, N.S.T., Behrman, A.N. \& Marsh, J.M. (1973) Preovulatory changes in the concentration of prostaglandins in rabbit Graafian follicles. Prostaglandins 3, 367-376.

Lindner, H.R., Tsafriri, A., Lieberman, M.E., Zor, U., Koch, Y., Bauminger, S. \& Barnea, A. (1974) Gonadotropin action on cultured Graafian follicles: induction of maturation division of the mammalian oocyte and differentiation of the luteal cell. Recent Prog. Horm. Res. 30, 79-127. 
McNatty, K.P., Makris, A., De Grazia, C., Osathanondh, R. \& Ryan, K.J. (1979) The production of progesterone, androgens and estrogens by granulosa cells, thecal tissue and stromal tissue from human ovaries in vitro. J. clin. Endocr. Metab. 49, 687-699.

Ménézo, Y., Gérard, M. \& Thibault, C. (1976) Culture du follicule de De Graaf de bovin dans un système à courant liquide et gazeux continu. C. r. hebd. Séanc. Acad. Sci., Paris D 283, 1309-1311.

Mōri, T., Suzuki, A., Nishimura, T. \& Kambegawa, A. (1977a) Inhibition of ovulation in immature rats by antiprogesterone antiserum. $J$. Endocr. 73, 185-186.

Mōri, T., Suzuki, A., Nishimura, T. \& Kambegawa, A. (1977b) Evidence for androgen participation in induced ovulation in immature rats. Endocrinology 101, 623-624.

Mōri, T., Kohda, H., Kinoshita, Y., Ezaki, Y., Morimoto, N. \& Nishimura, T. (1980) Inhibition by indomethacin of ovulation induced by human chorionic gonadotrophin in immature rats primed with pregnant mare serum gonadtrophin. J. Endocr. 84, 333 341.

Neal, P., Baker, T.G., McNatty, K.P. \& Scaramuzzi, R.J. (1975) Influence of prostaglandins and human chorionic gonadotrophin on progesterone concentration and oocyte maturation in mouse ovarian follicles maintained in organ culture. $J$. Endocr. 65, 19-25.

O'Grady, J.P., Caldwell, B.V., Auletta, E.J. \& Sperofi, L. (1972) The effects of an inhibitor of prostaglandin synthesis (indomethacin) on ovulation, pregnancy and pseudopregnancy in the rabbit. Prostaglandins 1, 97-106.
Osman, P. \& Dullaart, J. (1976) Intra-ovarian release of eggs in the rat after indomethacin treatment at prooestrus. J. Reprod. Fert. 47, 101-103.

Osman, P. \& Lieuwma-Noordanus, C. (1980) Ovulation from rat and hamster ovaries in vitro. J. Reprod. Fert. 59, $431-436$.

Taya, K., Saidapur, S.K. \& Greenwald, G.S. (1980) Interstitium: site of steroid synthesis in the ovary of the long term hypophysectomized hamster. Biol. Reprod. 22, 307-318.

Testart, J., Thébault, A. \& Lefèvre, B. (1983) In-vitro ovulation of rabbit ovarian follicles isolated after the endogenous gonadotrophin surge. J. Reprod. Fert. 68, 413-418.

Thébault, A. (1979) Maturation ovocytaire et steroidogénèse dans le follicule ovarien de la lapine, in vitro. Ph.D. thesis, Université Paris VI.

Tsafriri, A., Lindner, H.R., Zor, U. \& Lamprecht, S.A. (1972) Physiological role of prostaglandins in the induction of ovulation. Prostaglandins 2, 1-10.

Tsafriri, A., Koch, Y. \& Lindner, H.R. (1973) Ovulation rate and serum $\mathrm{LH}$ levels in rats treated with indomethacin or prostaglandin E-2. Prostaglandins 3, 461-467.

Wallach, E.E., Bronson, R., Hamada, Y., Wright, K.H. \& Stevens, V.C. (1975) Effectiveness of prostaglandin $\mathrm{F}-2 \alpha$ in restoration of $\mathrm{HMG}-\mathrm{HCG}$ induced ovulation in indomethacin-treated rhesus monkeys. Prostaglandins 10, 129-138.

YoungLai, E.V. (1978) Prostaglandins and steroidogenesis by isolated rabbit ovarian follicles. Hormone Res. 9, $31-40$.

Received 26 November 1982 